\title{
PALAEO-VALLEYS IN THE REGION OF THE SŁUPIA RIVER MOUTH
}

\author{
WACŁAW FLOREK \\ Pomeranian University, Department of Geomorphology and Quaternary Geology, Słupsk, Poland \\ StanisŁaw Rudowski, KaZimierz SZefler
}

The Maritime Institute, Department of Operational Oceanography, Gdańsk, Poland

Manuscript received: December 24, 2009

Revised version: August 1, 2010

Florek W., Rudowski S. \& Szefler K., 2010. Palaeo-valleys in the region of the Słupia River mouth. Quaestiones Geographicae 29(3), Poznań 2010, pp. 27-36, 8 Figs. ISBN 978-83-62662-04-3. ISSN 0137-477X. DOI: 10.2478/ v10117-010-0020-7.

ABSTRACT. Basing on results of detailed hydroacoustic research, the geological structure of the bottom to 20-22 $\mathrm{m}$ b.s.l. has been studied. The palaeo-Słupia palaeo-valley, buried by a thin cover of marine sands, has been recognized and determined. Some stages of valley development may be distinguished. The deposits of the oldest valley are $\mathrm{C}^{14}$ dated at ca. $21 \mathrm{ka} \mathrm{BP}$. But in the main stage, the valley was formed by action of the subglacial and thawing glacial waters during and after the so-called Gardno Phase. Most probably this valley was connected with the Pomeranian ice margin valley. The next stages of the valley's development were related with changes of the palaeo-Słupia under conditions of the Litorina transgression. The youngest palaeo-Słupia valley is, in the authors' opinion, related with a shallow, long incision, weakly marked in the sea bottom in the central part of the studied area. Field investigations were carried out by the Department of Operational Oceanography of the Maritime Institute in Gdańsk from the r/v Dr Lubecki. A DESO 15 echosounder, Subbottom Profilers model 3010 and the X Star system were used. Eight vibrocores (core length up to $3 \mathrm{~m}$ ) were taken from the sea bottom and three borings (10-17 $\mathrm{m}$ depth) were executed on the shore. Accurate positioning was obtained using the DGPS and HYDRO and Track Point Systems. All data were digitally recorded and processed.

KEYwORDS: Baltic Sea, palaeo-valley, Słupia river, hydroacoustic measurements

Wactaw Florek, Pomeranian University, Department of Geomorphology and Quaternary Geology, Partyzantów 27, 76-200 Stupsk, Poland, e-mail: florekw@apsl.edu.pl

Stanistaw Rudowski, Kazimierz Szefler, The Maritime Institute in Gdansk, Department of Operational Oceanography, Dtugi Targ 41/42, 80-830 Gdańsk, Poland, e-mail: kaszef@im.gda.pl

\section{Introduction}

Basing on a detailed analysis of materials and publications on the structure and development of the Lower Słupia region (among others: Rosa 1963, 1964; Uniejewska \& Nosek 1982, 1986,
Orłowski 1983a, b; Uścinowicz \& Zachowicz 1988, 1991; Florek 1989, 1991; Michałowska \& Pikies 1990, 1992) the structure of the Lower Słupia valley was presented (see Florek 2003), and three variants (Fig. 1) of the possible route of the river bed within the littoral zone were indicated. 


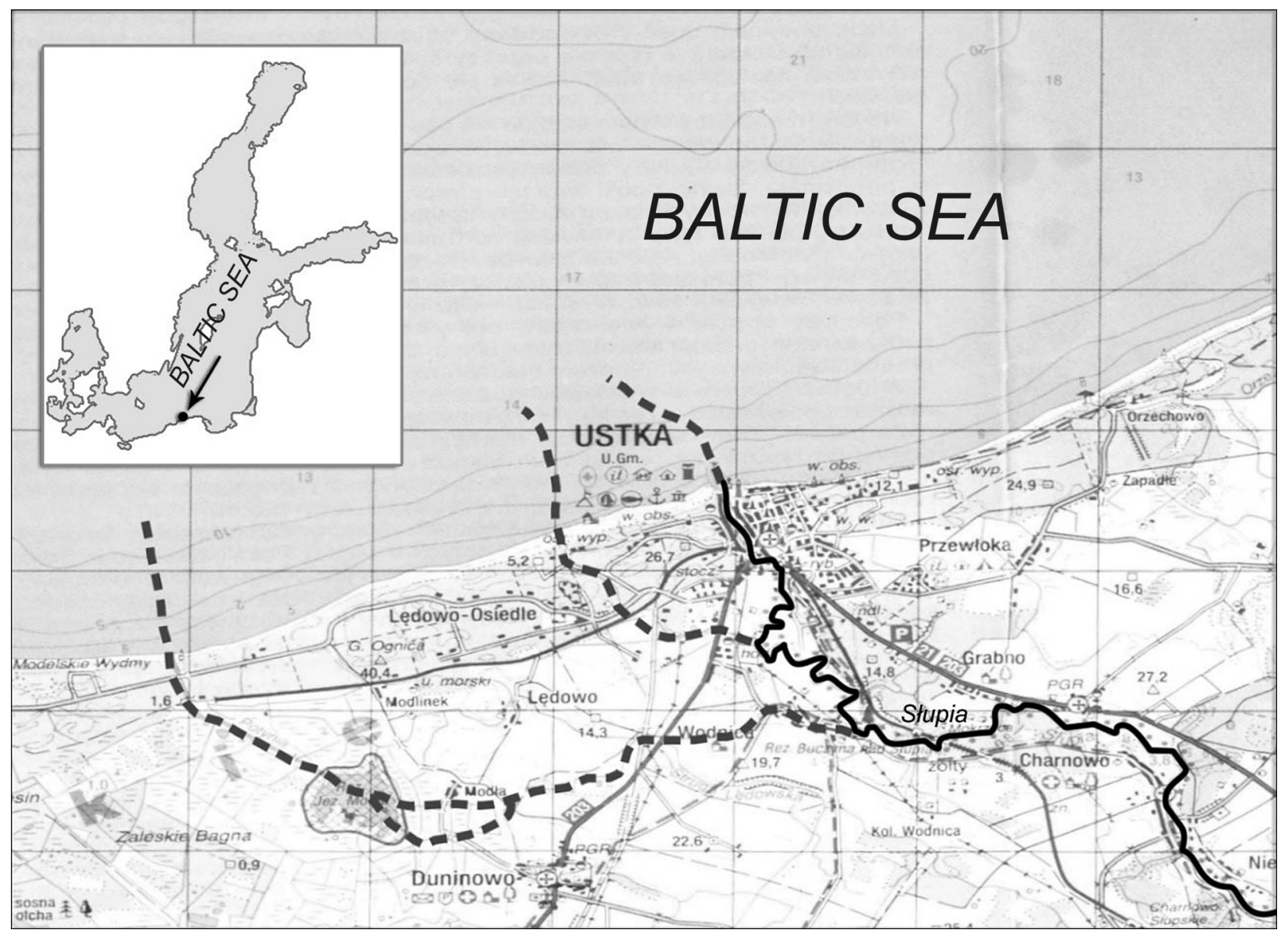

Fig. 1. Coast of Ustka Bay. Variants of possible routes of palaeo-Słupia river bed.

Western: Wodnica - Lake Modła - Potynia; central: Wodnica - Ustka - Czarna; eastern: Ustka-port - valley in sea bottom.

Solving the problem of the possible further route of the river bed of the palaeo-Słupia required investigating the structure of the sea bottom. On the other hand, during hydro-acoustic measurements, carried out up to 20-22 m water depth in 1997-2000, deep valley-like incisions were found, which were covered by a thin (up to $1 \mathrm{~m}$ ) layer of marine sand (among others Cieślak et al. 1998; Gajewski et al. 1998). This gave inducement to start detailed hydro-acoustic investigations of the sea bottom in the Ustka region, which provided a good recognition of sea bottom surface and structure.

\section{Aim, methods and scope of the investigations}

The aim of the investigations was to determine the route and state (degree of transformation due to transgression of the sea) of the part of the val- ley which at present is under the sea bottom. This primarily required:

- determining the area of investigations (on the basis of hitherto geological investigations of the Ustka area and of geological and geophysical investigations of the adjacent to land sea bottom area),

- determining the required methods of investigation,

- carrying out field and laboratory measurements,

- analysing the obtained data.

Field measurements at sea were carried out by the Department of Operational Oceanography of the Maritime Institute in Gdańsk from the research vessel $D r$ Lubecki. For positioning the DGPS system was used in connection with the Hydro and Track Point navigation systems. All data were digitally recorded in a continuous way, and digitally processed using the Coda 200 system. A single-beam DESO 15 echosounder operating at 

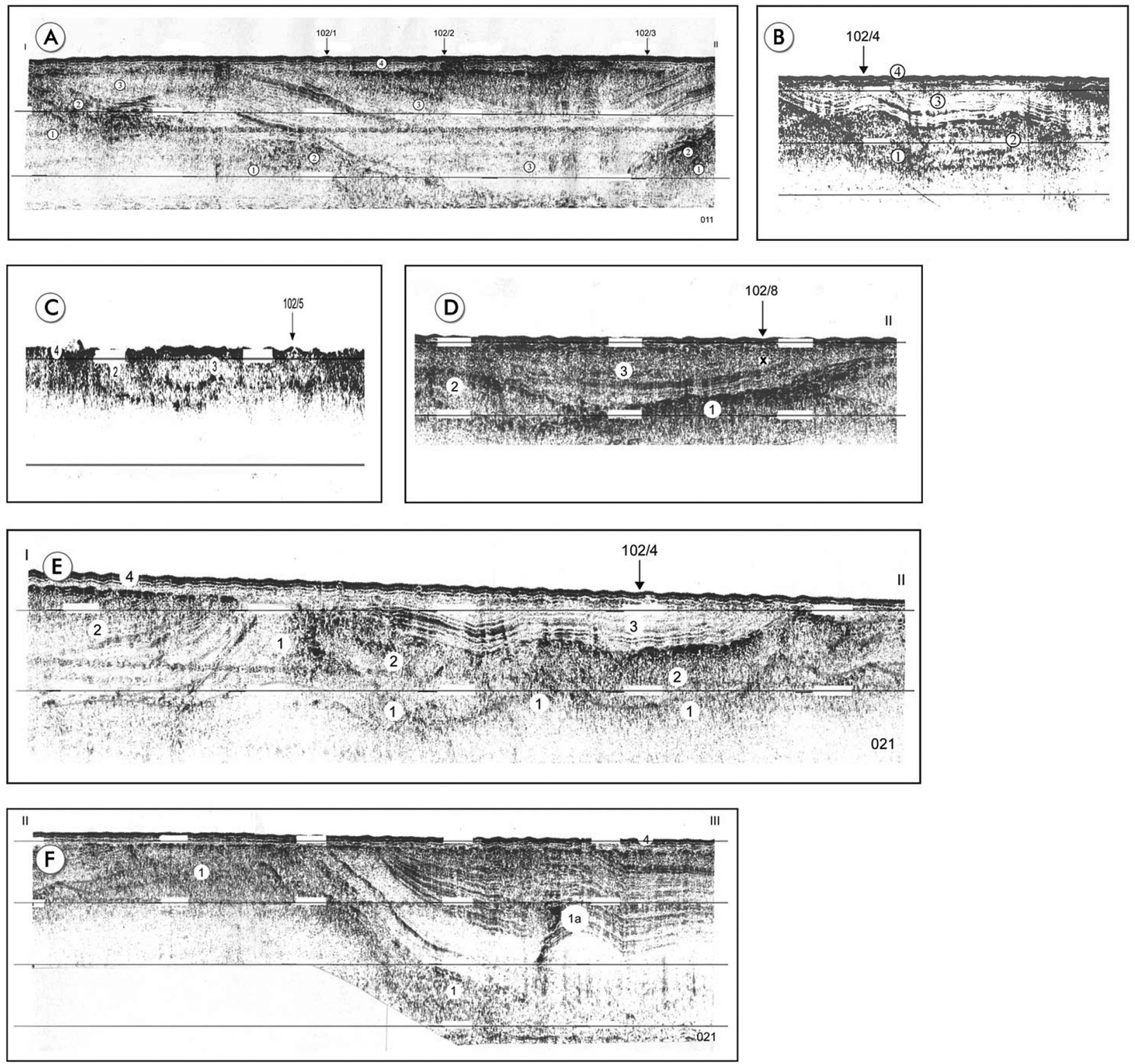

Fig. 2. Examples of seismoacoustic profiles, recording by X-Star system; explanations of units in the text. Horizontal lines at 12 and $17 \mathrm{~m}$ water depth.

$210 \mathrm{kHz}$ frequency, an X Star system profiler of sediments and a 3010 model bottom profiler were used. From the dense grid (500 $\mathrm{m}$ with additional supplementing lines) some exemplary parts of seismoacoustic profiles were selected and are shown in Fig. 2. At locations, selected in result of analysis of hydroacoustic records, 8 cores (of up to $3 \mathrm{~m}$ length) were taken from the sea bottom, and on land 4 borings to $10-17 \mathrm{~m}$ depth were carried out in the Słupia outlet area. The cores were macroscopically described in accordance with the Geodin system, and samples were taken from them for laboratory investigations.
The laboratory investigations included basic lithological analyses: grain size (sieve and aerometric), organic matter content (loss at roasting), carbonate content (Scheibler method) and content of trace elements (Florek et al. 2003). Also palinologic analyses for Cladocera content (Niska \& Miotk-Szpiganowicz in print) and 8 radiocarbon datings (Radioisotope Laboratory of the Silesian Technical University in Gliwice) were carried out.

Obtained results were used for the development of a detailed bathymetric map (Fig. 3), a map of the morpholithodynamic character of the bottom (Fig. 4) and of its structure (Figs. 5a, 


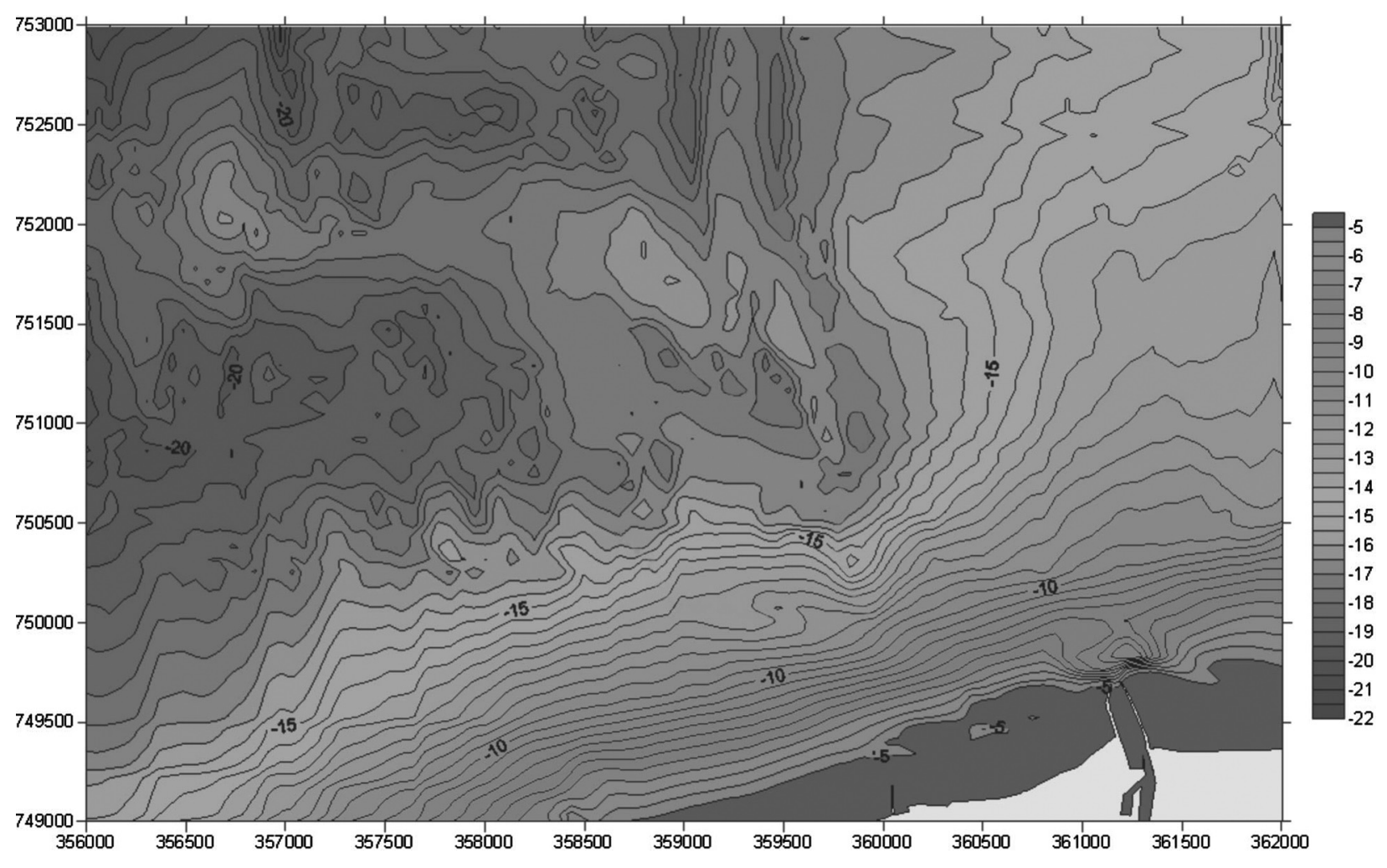

Fig. 3. Bathymetric map of investigated area.

$5 b, 6)$. The distinguished geophysical units were geologically interpreted and correlated with the data from the cores and bores. Next, lateral and vertical successions of the distinguished units were worked out.

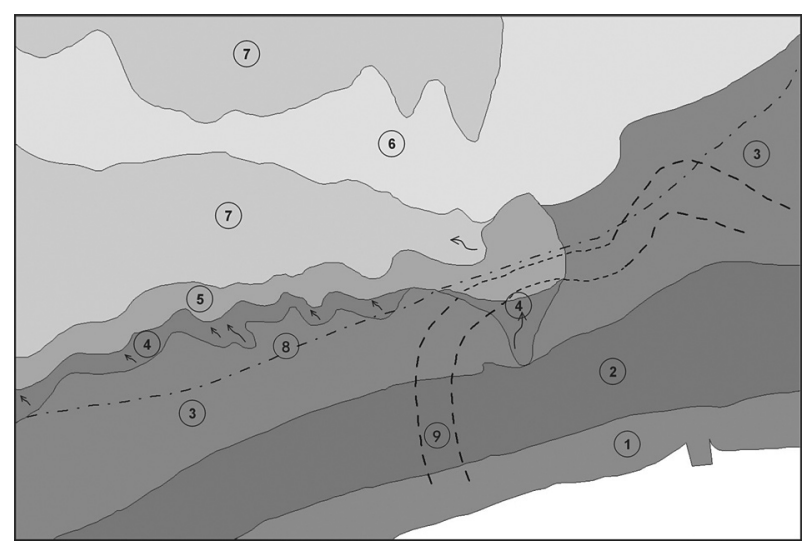

Fig. 4. Morphologic map of sea bottom in the Ustka region; shallow nearshore: 1 - breaker bar zone, 2 - coastal slope, deeper nearshore, 3 - fine sand redeposition zone, 4 - zone with prevailing marine erosion, 5 - leap deposition zone of various grained sediments; open sea bottom: 6 - sand wave zone, 7 - zone of continuous deposition of muddy sediments. Arrows indicate location of concentrated sediment transport to open sea, dotted line, 8 - indicates the southern boundary of ice margin lake sediments under marine sand cover, dashed lines, 9 - indicate the route of the covered palaeo-valley.

\section{Area of investigations}

The investigations covered a slightly over 4 $\mathrm{km}$ long outlet part of the Słupia valley, a several $\mathrm{km}$ long land area west of the outlet and the neighbouring sea area to a distance of 5-6 km from the coast to 20-22 m water depth.

The sea bottom relief and lithology are not especially diversified, with a nearly uniform sand cover (Michałowska \& Pikies 1990). However, the thickness of Quaternary deposits varies significantly (Uniejewska \& Nosek 1982, 1986), and in the opinion of Pikies (2000) in the Ustka region a large trough form is present, which cuts deep into the substratum. The structure, character and development of the outlet part of the Słupia valley has been synthetically presented by Florek (2003).

The Ustka region is an area characterised by high dynamics of coastal processes (Cieślak et al. 1998; Dziedzic 1989; Dziedzic et al. 1994). Strong wave action (with significant wave height up to $5 \mathrm{~m}$ ) together with high storm surges causes intense erosion of the nearshore bottom and the coast, which retreats at a rate of over $1 \mathrm{~m} \mathrm{y}^{-1}$ (in some years even 8-9 m). Since 1860 (after an extension of the breakwaters) a distinct impact of 


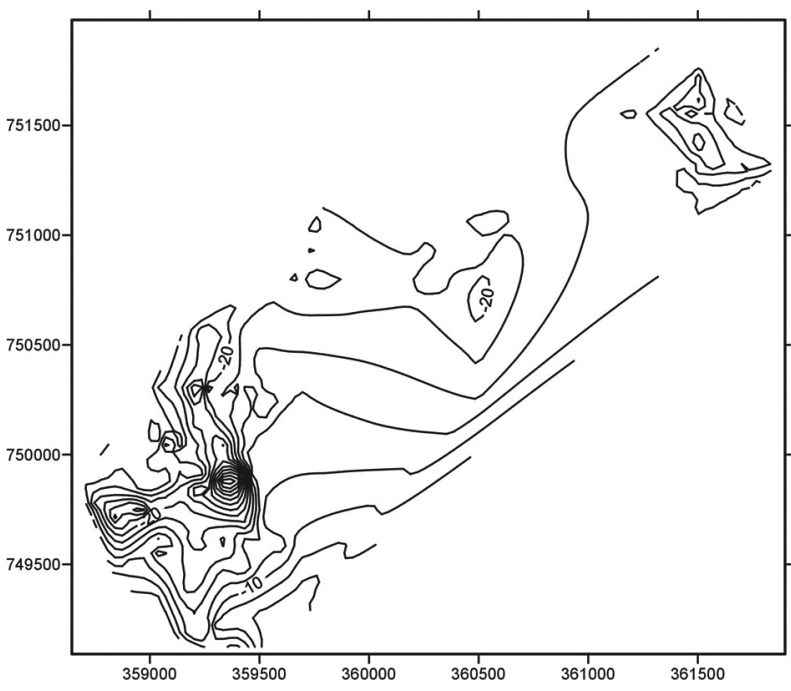

Fig. 5a. Map of palaeo-valley. Contour lines (related to mean sea level) of the surface of the cut into boulder deposits.

human economical activity is observed (Dziedzic 1989; Zawadzka 1999; Gajewski et al. 2003; Florek et al. 2009).

No traces of direct influence of the Słupia river on the sea bottom were found. There are no traces of concentrated erosion or accumulative forms; only traces of dredging works are visible (Rudowski et al. 2004).

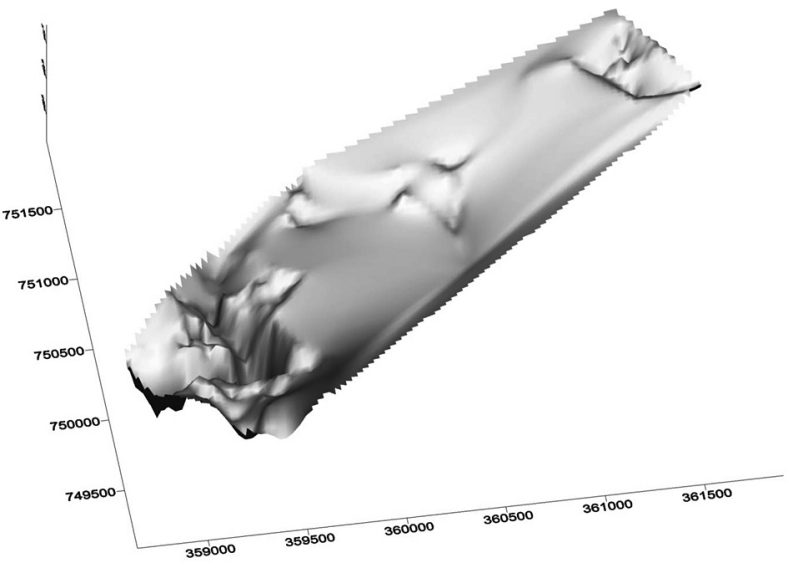

Fig. 5b. 3D picture of the palaeo-valley.

\section{Presumed route of the Słupia valley in the sea bottom}

Evaluation of the relief and sediments occurring on the surface of the valley forms indicates (Fig. 1) two main possibilities of shaping of the lower part of the Słupia valley during the late Vistulian glaciation. The first is flow through the present Lake Modła, the second, with more strongly marked erosion, is flow along the present bed of the Słupia. The third variant is the possibility of flow along the valley of a water-course discharging into the sea about $1 \mathrm{~km}$ west of the present outlet (Florek 2003).

$\mathbf{N}$

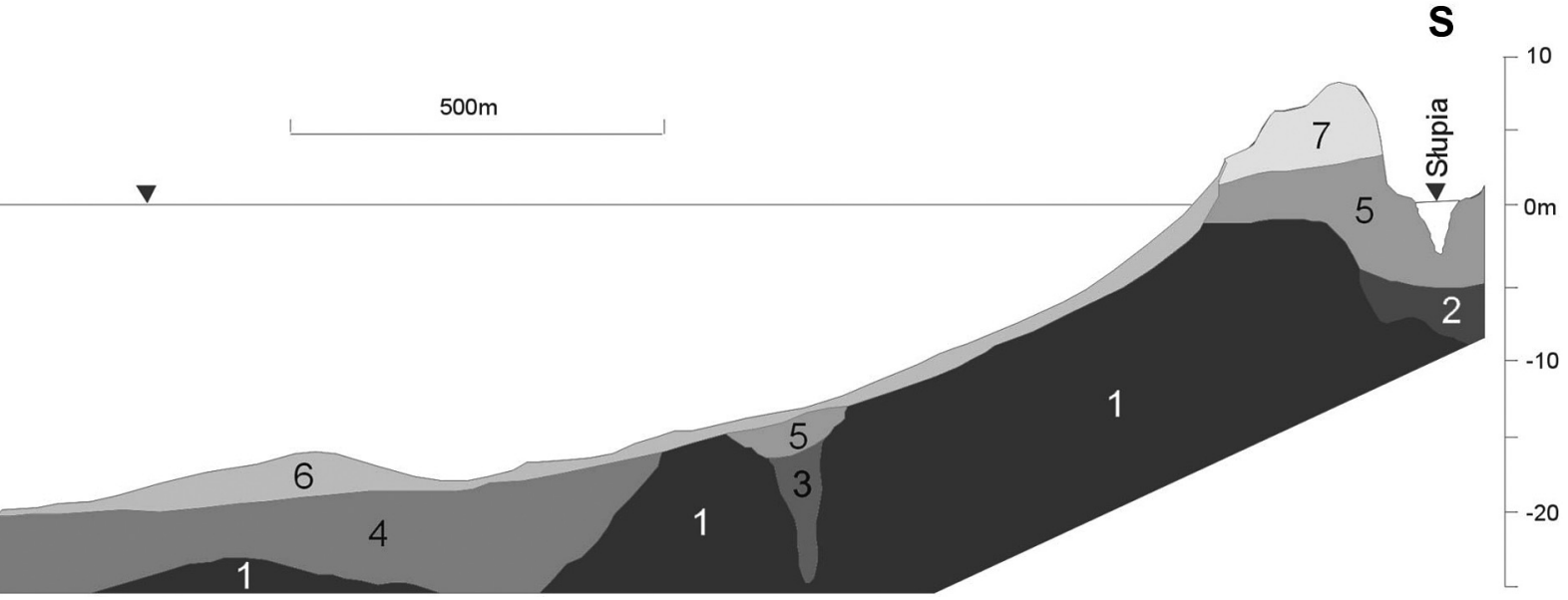

Fig. 6. Synthetic geological cross-section of the Ustka Bay coast along line 359250 E (Figs. 3, 5a, 5b); 1 - boulder deposits, 2 - lower ice margin lake deposits, 3 - glacifluvial sand and gravel, 4 - upper ice margin lake deposits, 5 - fluvial and bog limnic deposits, 6 - marine sand and mud, 7 - aeolian sand. 


\section{Results of the investigations}

\section{Character of bottom surface}

Basing on detailed analysis of sea bottom relief, pictured in the accurate bathymeric map (Fig. 3), and on analysis of data from seismoacoustic measurements which were carried out in a dense grid of profiles, several morpholithodynamic zones were distinguished in the bottom of the Ustka Bay (Fig. 4):

- shallow nearshore, water depth up to ca. 12 $\mathrm{m}$, including:

[1] breaker bar zone, water depth 0-5 m,

[2] coastal slope zone, water depth 5-12 m,

- deep nearshore, water depth 12-17 m, including:

[3] zone of fine and muddy sand redeposition,

[4] zone with prevailing marine erosion (water depth 15-16 m),

[5] various sand leap deposition zone,

- bottom of open sea (more than $17 \mathrm{~m}$ water depth) including:

[6] sand wave zone,

[7] zone of continuous mud sediment deposition.

In the part of the nearshore zone with prevailing marine erosion (zone 4, Fig. 4), where erosional armouring in the ceiling of boulder till and/or ice margin lake sediments is locally uncovered, there is a meridionally oriented, elongated, valley-like depression, with its axis situated at ca. $359750 \mathrm{E}$. At its outlet are over $1 \mathrm{~m}$ thick sand/mud sediments with boulders (identified in cores 102/5 and 102/6, nonlaminated, badly sorted, loosely packed aggregate of "massive" type). They are a part of the leap deposition zone of variously grained sand/mud sediments (zone 5) at 17-18 $\mathrm{m}$ water depth. This depression may be the route of present bottom sediment transport, using the old foundation of the palaeo-Stupia river bed, formed during the Littorina transgression at a sea level lower by 15-16 $\mathrm{m}$ than present. This possibility is also indicated by smaller belts of similar character, occurring in the neighbouring areas. A probable trace of the old palaeo-Słupia bed is also the depression located further seawards and reaching the open sea, which lies in line with the earlier described depression. The location of these, probably "littorina" beds of palaeo-Słupia is shown in Figs. 1 and 3.

\section{Sub-seafloor structure of the sea bottom}

The location of the distinguished seismoacoustic units is presented on parts of seismoacoustic profiles showing forms typical for the units (Fig. 2A-F). The lowest is the seismoacoustic unit 1 built of glacial drift sediments, till and (in the ceiling) aggregate and clayey sand containing boulders and blocks. Large parts of these formations are glacitectonically disturbed and have a scaly structure (e.g. in the part shown in Fig. 2E-F). The surface of the ceiling is uneven, of distinctly erosional character, with height differences reaching over a dozen metres. In deeper parts of the investigated area, on top of the glacial drift sediments, lie, nearly concordantly, marginal glacial lake sediments (unit 1A). In the lower parts the deposits are muddy, changing upwards into mud/clay, laminated deposits (Fig. 7F), with total thickness exceeding $17 \mathrm{~m}$. They reach nearly up to the seafloor, where they are erosionally cut away (and covered by marine sediments - Litorine and post-Litorine). Probably these deposits were formed in an ice margin lake. The southern boundary of the ice margin lake sediments (Fig. 4) runs obliquely across the middle of the investigated area. South of this line, in the bottom and under a cover of marine sediments, there are deep (over $15 \mathrm{~m}$ ) cuts into the boulder deposits, which form "valley" depressions. Their general route is shown in the morpholithodynamic map of the sea bottom (Fig. 4). The cuts (Fig. 2A, B, $\mathrm{D}, \mathrm{E})$ are filled with sand and gravel deposits, distinguished as unit 2 and determined as fluvioglacial sediments. On top of their erosionally transformed surface rest fluvioglacial and riverine mud and sand deposits of unit 3.

The youngest seismoacoustic unit (unit 4) is formed by the sand and mud cover of marine sediments, which is discussed in the previous part of the paper. It rests on a distinctly marked surface of erosional cutting off of older deposits. 


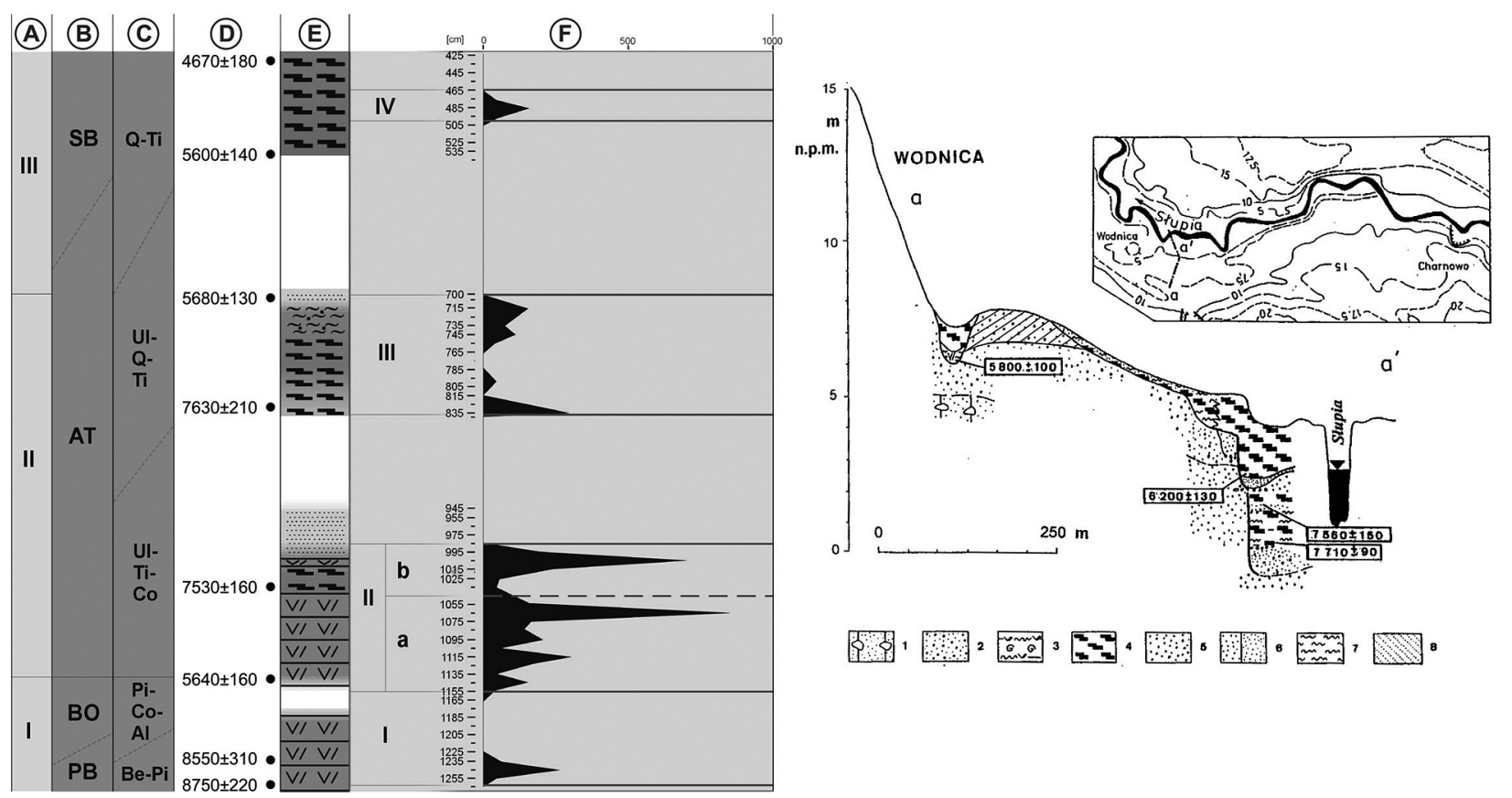

Fig. 7. Evolution outlet part of Słupia river valley; Ustka 3 profile; D - radiocarbon dates, E - lithology, F - Cladocera phases (after Niska, Miotk-Szpiganowicz in print), Wodnica cross-profile: 1 - grey till, 2 - various grained fluvial sand of first fluvial terrace, 3 - gyttja with malacofauna, 4 - peat, 5 - medium-grained channel-lag sands, 6 - medium- and fine-grained sands of point bars nad paleomeanders infillings, 7 - silts, 8 - aeolian sands (after Florek 1991).

\section{Structure and route of the palaeo-valley}

The location of the distinguished in Fig. 2 covered valley cuts is shown in the morpholithodynamic map of the sea bottom (Fig. 4) and presented in a depth contour map (Fig. 5a) and in the form of a 3D picture (Fig. 5b) of the surface of the ceiling of the substratum. These cuts represent a palaeo-valley of nonuniform character, with a clearly marked southern part and weakly visible eastern and middle parts.

The southern part is of a distinct valley form, cutting deep (over $15 \mathrm{~m}$ ) into the substratum (Figs. 2, 3, 6), with preserved terrace elements. In the lower parts of the cut occur weakly sorted sand/gravel, muddy glacifluvial deposits (of seismoacoustic unit 2). On them rest distinctly layered sand/mud deposits, interpreted as riverine sediments (of seismoacoustic unit 3). Two river beds, separated by a hump of an erosional remnant, are clearly marked here (Figs. 2D-E, 6). This part of the valley passes into an extensive accumulation cone form (?) in the area defined approximately by coordinates: $359750 \mathrm{E}$ i $750750 \mathrm{~N}$. At present this area is eroded, and deposits filling the valley become locally uncovered on the seafloor (Figs. 2D-E, 6) in the form of pavement and sandy diamictones, which probably are partly formed at present (cores 102/4 and 102/6).

The east part of the palaeo-valley is preserved only on a small area (Figs. 5a, 5b). It is of a similar character as the southern part, but cuts much less into the substratum and is more strongly cut off by erosion on the top. Sand/gravel deposits (seismoacoustic unit 2) are present here, and they are covered by muddy deposits passing upwards into clay/mud deposits with plant detritus (river mud?). The radiocarbon age of a sample taken from their ceiling part at $75 \mathrm{~cm}$ below the seafloor (core 102/8 in Fig. 2D) was determined by prof. A. Pazdur at the Radioisotope Laboratory of the Silesian Technical University in Gliwice at $21.4 \pm 0.73 \mathrm{ka}$ BP! This could indicate old (before the last glaciation) foundations of the valley (though it cannot be excluded of course that the dated sediment is located in a secondary deposit).

The middle part of the palaeo-valley is not clearly visible, and has the character of an extensive valley form, only slightly cutting into the substratum. Probably it was to a large extent destroyed and cut off by marine erosion during the process of sea transgression. It was not possible to prove definitely that the adopted hypoth- 


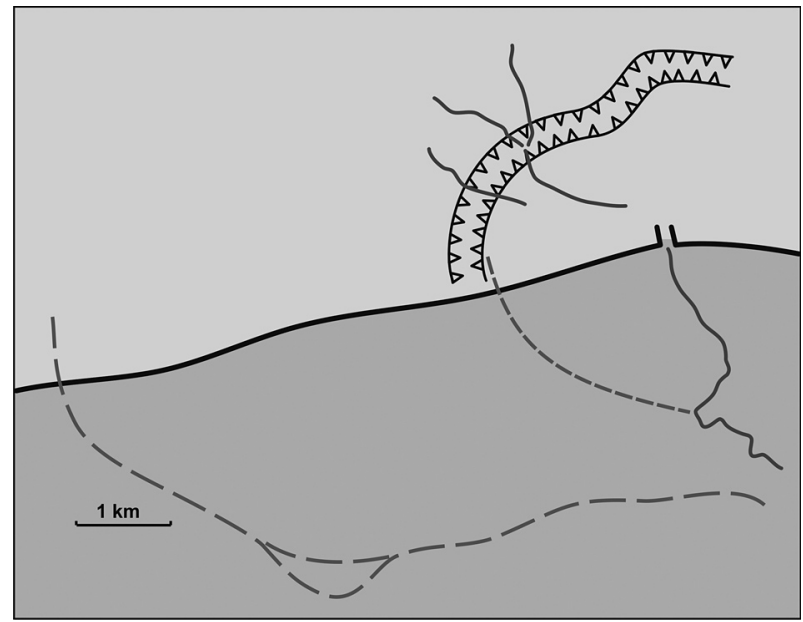

Fig. 8. Location of discovered palaeo-valley in the Baltic Sea bottom against Holocene river valley of the Słupia river.

esis about the relative uniformity of the palaeovalley, assuming its multistage development, is correct. Earlier it was also deemed possible that two independent beds of the palaeo-Słupia could have been functioning, and that they could have joined in the outlet section (Florek et al. 2003; L. Gajewski et al. 2002). New analysis of the seismoacoustic profiles, taking into account the effects of processes of marine erosion and accretion proceeding now on the sea bottom, suggest that the presently adopted hypothesis is more probable. With such assumptions, the development of the palaeo-valley was started before the advance of the continental glacier of the main phase of the last glaciation. This is quite similar to the valley cut observed in the bottom of the Odra Bank (Kramarska 1990, Kramarska et al. 2002), which is filled with sandy and muddy deposits with plant detritus radiocarbon dated at 45 to 22 ka years BP. The main stage of the valley's development was the formation of the deep cut caused by subglacial (?) operation of meltwater from the continental glacier, and next, during the Gardno phase, intensive accretion (units 2) in the ice margin valley. According to Marsz (1994) the Reda - Łeba ice margin valley and the valley situated in the sea bottom north of Lake Bukowo (Michałowska \& Pikies 1992), and the Gardno - Łebsko Lowland (Borówka \& Rotnicki 1995) also developed in a similar way.

Further development of the palaeo-valley was connected with a gradually decreasing flow, accompanied by formation of local still-water reservoirs and filling of the valley with fine sandy deposits. The rest of the route of the palaeovalley still remains an open question. Probably it reached the main ice margin valley, situated in the depression between the present coast and the Słupsk Bank (Mojski 1990, 1995; Uścinowicz 1999). It also cannot be excluded that the palaeovalley lead directly to the Bornholm Basin.

The lowering of the erosional base during the Yoldia Sea stage is at present not reflected in the structure of the sea bottom. Valley forms, developed at that time, could have been eroded away during sea transgression. The preserved part of the late Holocene palaeo-valley may be represented by the elongated depressions in the present seafloor (Fig. 3), which are meridionally situated in the central part of the investigated area. On first assumption, they could be seen as relics of the Late Glacial - Upper Holocene Słupia valley. Some supporting indications are obtained from the analysis of geological sections carried out earlier for the Wodnica area (Florek 1991) and from bores obtained during the present cycle of investigations (Rudowski et al. 2004; Niska \& Miotk-Szpiganowicz in print) (Fig. 7). However, this requires further investigations in order to determine the scope and range of contemporary sea bottom erosion and accretion.

\section{Conclusions}

The palaeo-valley, investigated using non-invasive methods of measurement, is most probably a valley form shaped in an earlier period, and is largely filled with aggradation type sediments, as is indicated by the thickness of the deposits (it is at least three times thicker than the depth of reworking of sediments in a river of the size of present Słupia). Moreover, the radio-carbon age of organic matter occurring in the ceiling of mud deposits (core 102-8) in the sea bottom was determined at $21.4 \pm 0.73 \mathrm{ka} \mathrm{BP}$. In core 102-3, where nearly identical deposits are present, G. MiotkSzpiganowicz determined a palynologic picture of the sequence of changes in a cold environment (it can be assumed that the analysed deposits were formed in the anaglacial phase of the last glaciation). Therefore, assuming that similar mud deposits were eroded from the valley area, the located between these bores valley form may 
be filled with deposits of the same or older age. This means also the adoption of the thesis that the valley form (of the palaeo-Słupia) north of Ustka is a surviving, maybe many times reproduced, form.

Deposits occurring on land, in bores Ustka-1, Ustka-2 and Ustka-3, contain the geological record of the sequence of events connected with the filling of depressions (with imprecisely determined genesis), which between the Boreal and the end of the Atlantic period were covered by bogs and shallow eutrophic lakes. During burning of samples at the Radioisotope Laboratory of the Silesian Technical University in Gliwice a large sulphur compound content was found, which can be considered as proof of anaerobic conditions in these reservoirs. This lead Niska \& Miotk-Szpiganowicz (in print) to the conclusion that these conditions were provided by eutrophic lakes. Authors of the present paper are of the opinion that the conditions were provided not by lakes, but by old river beds, which gradually became filled with lacustrine and then bog deposits. This is confirmed both by the sequence of deposits found in the earlier mentioned bores, and the sequence of radiocarbon dates of peat from the bore Ustka 3 which are from $8.55 \pm 0.31$ to $4.67 \pm 0.18$ ka years BP (non-calibrated dates, acc. to determinations of prof. A. Pazdur, Fig. 7).

The breaks in accumulation of organic matter should be interpreted as the effect of inflow of Słupia waters, which gave an aggradative effect, identical with the effect described by Florek $(1991,2003)$ for Wodnica station, which is located $4 \mathrm{~km}$ upriver.

In connection with the presented above considerations, the scope of change of the lower Słupia's route still remains an open question. One possibility is the flow of Słupia waters (Figs. $1,8)$ through a depression between Wodnica and the present Lake Modła, and next through Potynia to the area of present Baltic Sea, or from Wodnica to the bed of Czarna which discharges into the Baltic in the area of the Police Training Centre. In both cases the route leads through terrain which at present is at $+4 \mathrm{~m}$ a.s.l., where no clear valley form has been shaped, and where deposits, which could be considered as fluvial, are yet to be found. It results that flow by that route could have occurred only during the late glacial period, directly after the ice margin forms occurring in the Bydlino region were broken. Moreover, the duration of the flow must have been very short (no typical fluvial forms were shaped and there is a lack of typical fluvial deposits). In effect everything points to the location of the late glacial and early Holocene Słupia in the area of its present outlet ( the geological content of bore Ustka-4 provides evidence that the river bed did not move sideways from west to east).

The observed meridional valley-like depression in the sea bottom, located along the 359750 E coordinate (Figs. 3 and 8), with distinct traces of concentrated erosion and accretion, has also a weakly marked trace under the marine sand cover. It is highly probable that this is the preserved trace of the late Holocene valley of palaeoSłupia, which at present is undergoing further transformation caused by marine processes.

\section{Acknowledgements}

The investigations were carried out in the framework of the grant KBN 8 T122E 06221 in the years 2001-2004 (Florek et al. 2004, Rudowski et al. 2004).

\section{References}

BorówKa R. K. \& RotNicki K., 1995. Problems of Lower and Middle Quaternary of the Gardno-Łeba Lowland. In: W. Florek (ed.), Geologia i geomorfologia Pobrzeża i potudniowego Battyku 2: 53-70.

Cieślak A., Gajewski J. \& Gajewski L., 1998. Dynamics of sea bottom and coastal erosion in the area of the power cable. WW Instytutu Morskiego 5347, Gdańsk.

DzIEDZIC W., 1989. Geodynamics of the coast in the Ustka region. Studia i Materiaty Oceanologiczne 55: 87-106.

Dziedzic W., FloreK W. \& KonARSKi P., 1994. Changes of coastline along the stretch Ustka-Rowy in the light of historical maps and contemporary survey materials. Konferencja "Geologia i geomorfologia Pobrzeża i Południowego Battyku", Słupsk: 76-77.

FLOREK W., 1989. The Late Vistulian and Holocene evolution of the Słupia river valley. In: W. Florek (ed.), Ewolucja doliny Słupi w późnym vistulianie i holocenie. Zeszyty Naukowe AGH, Geologia 15(1-2): 158-184.

FLoREK W., 1991. Postglacial development of river valleys in the middle part of the northern slope of Pomerania. Wyższa Szkoła Pedagogiczna, Słupsk.

FLOREK W., 2003. Conjectural course of the Słupia river valley on the bottom of the Baltic Sea in the light of evidences from land area In: W. Florek (ed.), Geologia i geomorfologia Pobrzeża i potudniowego Bałtyku 5: 81-87. 
Florek W., Gajewski L., Lubomirski K. \& Rudowski S., 2003. Lower valley of Slupia River onshore and offshore structure and development. Proceedings Baltic Sea Science Conference, Helsinki, 94.

FloreK W., KaczmarzyK J. \& MajeWski M., 2009. Factors affecting the intensity and character of cliff evolution near Ustka. Oceanological and Hydrological Studies, XXXV, supplement 1: 9-25.

Florek W., Rudowski S. \& Szefler K., 2005. Palaeovalleys in the Ustka Bay bottom. In: W. Florek (ed.), Geologia i geomorfologia Pobrzeża i potudniowego Bałtyku 6: 89-103.

GAJEWSKI J., GAJEWSKI L. \& RUDOWSKI S., 1998. Geological condition of the coastal zone near Ustka. Report for horizontal guided drilling purposes. WW Instytutu Morskiego 5374, Gdańsk.

Gajewski L. \& Rudowski S., 2000. Coastal monitoring in the HVDC cable landing zone in Ustka. WW Instytutu Morskiego 5621, Gdańsk.

GajeWSKi L., Rudowski S. \& Szefler K., 2002. Identification by hydroacoustic methods of river valleys below the coastal seafloor. In: Materiaty 5 Konferencji "Geologia i geomorfologia Pobrzeża i dna południowego Battyku", Słupsk-Ustka 6-8 czerwca 2002, Słupsk: 27.

Gajewski L., Gajewski Ł., NowaK J. \& Rudowski S., 2003. Coastal monitoring in the power cable landing area. Influence of laying the HVDC cable on the lithodynamic balance of the coastal zone. WW Instytutu Morskiego 6008, Gdańsk.

Kramarska R., 1990. Origin and development of the Odra Bank. Geological Quarterly 42: 277-288.

Kramarska R., Uścinowicz S. \& Zachowicz J., 2002. Southern Baltic Cainozoic - selected problems. Przegląd Geologiczny 8: 709-716.

Marsz A., 1994. Problems connected with the genesis of the ice margin valleys of the Kashubian Coast. Przeglad Geograficzny 1-2: 169-184.

MichaŁowsKa M. \& Pikies R., 1990. Geological map of Baltic Sea bottom in scale 1:200 000, Sheet Koszalin. Warszawa.

MichazowsKa M. \& PIKIES R., 1992. Explanations to the 1:200 000 geological map of Baltic Sea bottom, Sheet Koszalin. Warszawa.

MојSKI J., 1990. The Vistula delta. In: L. Starkel, E. Wiśniewski (eds.), Evolution of the Vistula River Valley during the last 15000 years, part III. Geographical Studies Special Issue 5: 126-141.
Mojski J. (ed.), 1995. Geological Atlas of the Southern Baltic in scale 1:500 000. Explanations. Sopot-Warszawa.

Niska M. \& MiotK-SzPIGANowicz G., in print. Biostratygraphic investigations of Słupia valley deposits. In: W. Florek (ed.), Geologia i geomorfologia Pobrzeża i potudniowego Battyku, 8.

OREOWSKI A., 1983a. Lithostratygraphy and palaeo-geomorphology of the Stupia valley. Doctor's thesis, typescript in the Chair of Physical Geography of the Gdańsk University.

ORŁowSKI A., 1983b. Pleistocene history of development of the Słupia valley. In: Pomorskie środowisko przyrodnicze, 11: 263-295.

PIIIES R., 2000. Subglacial valleys in selected areas of the southern Baltic Sea. Proceedings of the Sixth Marine Geological Conference The Baltic, Sopot.

Rosa B.,1963. On the morphological development of the Polish coast in the light of ancient coastal forms. Studia Societatis Scientarum Torunensis 5.

RosA B., 1964. On alluvial and biogenic forms resting in valleys of Baltic coast rivers, and on their relationship with sea transgression and importance for investigations of the neotectonics of the area. Zeszyty Naukowe UMK, Geografia 11: 85-99.

RUDOWSKI S., FloREK W. \& SZEFLER K., 2004. Determination of the state of river valleys in the sea bottom by noninvasive methods on the example of the Słupia valley. WW Instytutu Morskiego 6103, Gdańsk.

UniejeWsKa M. \& Nosek M., 1982. Detailed geological map of Poland in 1:50 000, Sheet Ustka. Warszawa.

UNIEJEWSKA M. \& NoseK M., 1986. Explanations to the detailed geological map of Poland in 1:50 000, Sheet Ustka. Warszawa.

UścinOwicz S., 1999. Southern Baltic area during the Last Glaciation. Geological Quarterly 2: 137-148.

UścinOWicz S., 2003. Relative sea level changes, glacio-isostatic rebound and shoreline displacement in the southern Baltic. PIG Special Paper 10.

Uścinowicz Sz., Zachowicz J., 1988. Geological map of Baltic Sea bottom in 1:200 000, Sheets Łeba, Stupsk. Warszawa.

Uścinowicz S., ZACHOWICZ J., 1991. Explanations to the geological map of Baltic Sea bottom, Sheets Łeba, Stupsk. Warszawa.

ZAWADZKA E., 1999. Trends of development of the Polish coast of the Southern Baltic. Gdańsk. 